\title{
Office Design and Dignity at Work in the Knowledge Economy
}

\author{
by Ralitza Nikolaeva ${ }^{\mathrm{a}, \mathrm{b}}$ and Silvia Dello Russo ${ }^{\mathrm{b}}$ \\ ${ }^{a}$ Graduate School of Business, Nazarbayev University, Astana, Kazakhstan \\ ${ }^{\mathrm{b}}$ Business Research Unit, ISCTE-Instituto Universitario de Lisboa, Lisbon, Portugal
}

\section{SUMMARY}

The current chapter looks at a grossly overlooked aspect affecting employee dignity in the workplace - the physical environment. While the knowledge economy has grown tremendously in the last four decades, researchers have not paid much attention to the new needs of the physical workspace despite the fact that office buildings represent the second largest financial overhead after human resource. At the same time, the physical space is a critical element in the organization of the processes, activities and ultimately the power structure of any organization.

Dignity in itself has not been in the center of management and organizations research, either. The few scholars who have written on the subject have mostly relied on writings in philosophy, sociology, political science, and law. We use their deconstruction of dignity into matters of identity, autonomy, dependency, seriousness, and trust to link the concept to the studied effects of the office physical environment on employees.

The chapter presents an overview of the different elements of the workspace environment that have been subject of interest to researchers and their effects on employees. The characteristics of the physical environment are organized in three broad groups: (i) the office structure and layout (e.g., enclosed offices vs. open plans, the presence of other barriers, the size), (ii) the office décor and design (e.g., furniture and equipment), and (iii) ergonomic aspects such as lighting, noise, temperature, and air. Their effects are expressed at multiple levels and encompass broad outcomes ranging from individual physical and psychological wellbeing to job satisfaction to team cohesion and organizational performance. The important point is that employees are almost never consulted on their preferences for elements of the office design and that there is no recognition for the need for different solutions for different types of employees and contexts. This state of affairs brings the question of employee dignity into the picture.

The chapter concludes by linking the elements of the physical environment of the $21^{\text {st }}$ century office to the concepts of power and dignity. We make three basic points. First, the knowledge economy is increasingly dependent on knowledge workers who are narrowly specialized and hence tend to have different needs in the workplace. Second, decisions about the physical environment are extremely complex and giving agency to employees in these decisions is crucial because of knowledge workers' high demands of autonomy. Third, due to this complexity, a systems approach is best suited to abet the understanding of the place of the physical workspace in a constantly evolving organic system of people and organizations. We suggest that such an approach taking into consideration the physical 
environment and its effect on workplace dignity can be a road to reconciling the often conflicting organizational and employee interests. 
The spaces and places around us construct us as we construct them.

(Dale \& Burrell, 2007, p. 1)

When we decided to write this chapter, we posed the question of the meaning of dignity at a dinner party on a summer night in a lovely Lisbon patio. Not surprisingly, each of the guests (all highly educated individuals) felt quite comfortable with the term and yet everyone had a different notion of what dignity is. We suspect this is the state of affairs not only at our dinner party as Kateb (2011, p.1) observes: "It almost seems as if the idea of human dignity is axiomatic and therefore requires no theoretical defense." Sayer (2014) further attests that dignity is more often used as a criterion or ultimate value rather than defined in the literature.

The literature tightly links dignity to human rights and, therefore, to something inherent to all human beings. Not surprisingly, Kateb (2011) puts together dignity with human identity. Identity also has wide room for interpretation, yet Kateb (2011) calls the component of individual identity primordial. When we talk about human dignity and human rights we often refer to the "inhumane" treatment of individuals by other individuals or the denial of dignity. When we talk about dignity at work, we have to change the perspective. In this chapter, we look at work conditions in the knowledge economy in Western societies. Fortunately, this is not the place where dire violations of human rights occur. However, there is a lot more to look at in the context of office environments than just the lack of flagrant human rights violations. In fact, Bolton (2010) says that the ultimate question behind all workplace experiences is whether we derive dignity from our labor. Pirson and Dierksmeier (2014) propose that the notion of dignity historically has evolved along two main lines - unconditional due to the intrinsic value of being human, and conditional due to people's actions. In that aspect, the managerially relevant division is that unconditional dignity needs protection and conditional dignity needs promotion. Based on this notion, the authors suggest two corollaries: 1) protecting dignity is a necessary condition and 2) promoting dignity is a sufficient condition for social welfare creation.

Hodson (2001, p.3) defines dignity in the economic terms of demand for a living wage and equal opportunity, whereas at the workplace "dignity is realized through countless small acts of resistance against abuse and an equally strong drive to take pride in one's daily work". The author elaborates that the workplace, in fact, turns into the major arena for the realization of human dignity. Because human beings act creatively and purposefully, the workplace provides the greatest opportunity to manifest personal agency. On the flipside, the workplace also provides ample openings for the denial of dignity. Hodson (2001) lists four major workplace denials mismanagement and abuse, overwork, constraints on autonomy, and contradictions of employee involvement. Bolton (2010) goes further and comes up with ten dimensions of dignity dividing them into subjective and objective factors - dignity in work (autonomy, job satisfaction, meaningful work, respect, learning \& development) and dignity at work (wellbeing, just reward, voice, security, equal opportunity). Ultimately, we should care about dignity because promoting it can result in wellbeing and flourishing as shown in various studies in developmental economics, psychology and organizational research (Pirson, 2014).

This chapter will look at a grossly overlooked aspect affecting employee dignity in the workplace - the physical environment ${ }^{1}$.

\footnotetext{
${ }^{1}$ The literature on the physical environment in the workplace is widely fragmented with various terms in use including: space, place, surroundings, locale, built environment, workspace, building, organizational space, etc. (Taylor \& Spicer, 2007). We use some of these terms interchangeably throughout the chapter.
} 


\section{Offices and work spaces in the knowledge economy}

Ironically, even though the interactions between organization, space and architecture have deep influences on our daily lives, it might be that the physical environment has become so overlegitimized and institutionalized that we do not notice it any more (Dale \& Burrell, 2007). When we talk about the physical elements of the workplace, we will concentrate of the workspace of knowledge workers, commonly understood as “office". We agree with Dale and Burrell's (2007) observation that workspace has become a problematic concept as work has been spilling in all sorts of alternative locations, but here we will focus only on the "office". While the knowledge economy has grown tremendously in the last four decades, researchers have not paid much attention to the new needs of the physical workspace associated with the knowledge economy despite the fact that, for many organizations, components of the physical environment represent the second largest financial overhead (Ashkanasy, Ayoko, \& Jehn, 2014). It does not appear that much has changed in the last twenty years since Vischer (1995, p.34) wrote: "Because white-collar and "knowledge" work does not depend on fixed equipment..., accommodation decisions tend to exist in a limbo between "dollars" and "image" - a trade-off that a few senior executives and their favorite architect usually make."

Powell and Snellman (2004) observe that the long term productivity gains of the knowledge economy may not be fully realized until they are accompanied by matching alternations of organizing. The physical space is a critical element in the organization of the processes, activities and ultimately the power structure of any organization (Foucault, 1977). Kornberger and Clegg (2004) present an overview of the importance of space in management theory - from Taylor and Weber to Peters and Hatch in the nineties. Organizing and space move in perpetual cycles of inputs and outputs and while the Foucault's space may be more abstract, space in management research has predominantly tangible qualities. However, it is the "imaginary' aspect of materiality" (Dale \& Burrell, 2007) that is of greater interest to us. In fact, "the physical environment may be utilised [sic] to give tangible expression to a desire for greater control over the work process" (Barnes, 2007, p. 247). Yet, for some reason, work space design is quite marginal in management and psychology research (Knight \& Haslam, 2010).

In the knowledge economy office environments are still governed by the paradigm of rationalism and Taylor's idea of scientific management. The doctrine dictates tight managerial control of the office space, which is to be designed in simple and efficient ways and mostly benefiting the clients or customers rather than the employees occupying it (Knight \& Haslam, 2010). But the knowledge economy is increasingly dependent on professionals whose skills are not easy to replicate. Therefore, autonomy remains one of the crucial factors for the workplace at current times. While the twenty-first century has brought great advancements in employee participation and involvement in various areas of the workplace, office design tends to be among the last frontiers. It is interesting to note that in an overview of the effects of the physical environment of the office in the contemporary organization, Davis, Leach, and Clegg (2011) talk mostly about prescriptive approaches rather than empirical findings in their section on the form of the evolving office. Hodson and Roscigno (2004) observe that there is no single organizational or job-level practice that would bring an optimal balance between the organization's objectives and employee wellbeing, but rather we have to look for certain configurations of practices that can achieve both objectives. Thus, we situate the design of the physical workplace environment as an overlooked factor that can contribute to the optimal balance between organizational and employee interests. 
Office design has been primarily based on fashions among designers, developers and managers ${ }^{2}$. In fact, there is a predominant view among researchers that the Tayloristic approach to office space design is more based on ideology rather than empirical evidence (Knight \& Haslam, 2010). Even in new attempts to re-design the workplace according to the demands of the $21^{\text {st }}$ century office, design decisions are frequently based on managers' perceptions and no research or employee input. The common factors driving changes in contemporary offices are cost reductions, technological advances, and the prevalence of knowledge workers' diverse set of tasks (Davis et al., 2011). The modification of open-plan offices is an example of a trend that has to a large extent ignored employee preferences and dignity. While there is mounting evidence that the primary rationale for open-plan offices is cost savings and surveillance (Barnes, 2007; Davis et al., 2011), there is a narrative for "coolness", "creativity enhancement", and transparency that has been propagated by star designers, sketchy research and, lately, the visibility of "cool" companies like Apple, Google, and Facebook. Research shows, though, that employees are almost never consulted on their preferences for elements of the office design regardless whether the design is lean and efficient or enriched to enhance employees' comfort (Knight \& Haslam, 2010).

The lack of voice in office design is in contrast to recent trends of increased employee participation (Hodson, 2001), which is crucial for fostering employee citizenship behavior. In essence, the physical aspect of the workplace environment more often than not shows no recognition for the need of different solutions for different types of employees and contexts. Consequently, employees have to settle for workplaces that are not only not meeting their needs, but in some cases are detrimental to their psychological and physical wellbeing. The missing employee involvement has led some authors to such extremes as comparing office space to sweat shops and slave galleys (Knight \& Haslam, 2010), which are deniers of dignity par excellence. In more down to earth terms, the resulting employee frustration is expressed in this quote: "And the thing that sticks in most people's gullets is that the people who advocate open plan don't work in it themselves. To me that's double standards." (Baldry \& Barnes, 2012, p.237). The quote touches on two aspects directly related to dignity - the denial of autonomy and fairness. Barnes (2007, p.257) makes the explicit connection: "employees' perceptions of autonomy and dignity exert a significant influence in shaping struggles over the built environment."

Closely related to the question of the relationship between workspace design and employee dignity is Foucault's (1977) idea of the relation between architecture and control, architecture and discipline. Foucault carefully dissects the role of the architectural space in the exercise of power. Power and politics are communicated through the physical space (Dale \& Burrell, 2007). The idea of the panopticon as an instrument of dehumanization and internal imposition of discipline to fit in societal norms is perfectly applicable to the design of workplaces as observed by various scholars (Bain \& Taylor, 2000; Kornberger \& Clegg, 2004). The panopticon in the form of open-plan structures puts additional pressure on employees not only by managers, but also by their peers to work harder for the goals of the organization without consideration of their individualities (Knight \& Haslam, 2010). Thus, the panopticon can serve as a metaphor of the wipe-off of employee dignity as it does away with autonomy and, consequently, qualifies as a major denier of dignity in Hodson's (2001) framework.

\footnotetext{
${ }^{2}$ Vischer (1995) offers an informative description of how workspace decisions are made.

${ }^{3}$ Here is quote from a Google employee: “... if you have to work in one of the four main campus buildings, you will most likely be extremely cramped. It's not uncommon to see 3-4 employees in a single cube, or several managers sharing an office. With all the open areas for food, games, TV, tech talks, etc, it can be surprisingly hard to find a quiet, private place to think." (Edwards, 2015)
} 
The architecture of control on its part falls in line with the overall subscription of the management and organization sciences to the paradigm of homo economicus or the mechanistic view of human behavior as a series of optimization problems of increasing benefits and decreasing costs. This paradigm is so ingrained in our disciplines that even when authors call for researchers to move beyond "basic productivity/business outcomes" and include human behavior, they propose the following strategy: "the provision of bottom line indicators would enable I/O psychology researchers to offer a credible argument in favor of design choices that may not be the most financially attractive in the short run, but which deliver longer term human and organizational benefit" (Davis et al., 2011, p.227). If employees are yet another resource, value needs to be extracted from them as from any other resource. Control and discipline are efficient tools in the process of value extraction, hence the value of the panopticon. Therefore, some scholars call for complete rejection of the terminology "human capital" and "human resources" and instead reconceptualizing business around human relations (Dierksmeier, 2011).

The number one reason for management and organizational scholars to study workspace is its relation to organizational goals and performance. The underlying assumptions of any intervention on the physical work environment typically fit within either of two paradigms: a Tayloristic approach aimed at increasing efficiency by reducing costs or wastages, or an "enrichment" approach - rooted in the job design characteristics model (Hackman \& Oldham, 1976) - aimed at increasing productivity via motivating employees to outperform. The article by Vischer (1995) is a typical example of these guiding motivations. There the author cites companies, such as Apple, that have found out that strategic workspace planning can empower employees to make their own decisions regarding their space that can lead to cost savings for the company. Is this really the type of empowerment promoting dignity? We aim to provide an answer to this question in the remainder of this chapter.

In the next section we review the empirical research on physical workspace and its consequences, together with the proposed theoretical mechanisms that would explain such relationships. A stylized summary is reported in Table 10.1. In light of this literature and the theoretical perspectives on dignity presented above, the connections and overlaps between the two streams of literature will become apparent, and are further outlined in Table 10.2. We close our chapter with concluding thoughts on the intricacies between physical space, power and dignity, and by calling the attention to an overlooked topic.

\section{Features of the physical work environment and their effects on employees}

Taylor and Spicer (2007) classify the existing studies of organizational spaces into three categories: space as distance; space as the materialization of power relations; space as experience. While in the first case the approach is more mechanistic involving objective measurements of distance, investigating power relations and experiences relies much more on interpretive approaches. For our purposes, we are more interested in the way the physical workspace relates to power and experiences, because even distances are interpreted to ultimately affect experiences. Certainly, Foucault's influence is a major source of inspiration when discussing power relations, though there have been accusations that scholars tend to concentrate on one particular work - Discipline and Punish (Carter, 2008; Knights, 2002). The image of the panopticon as an instrument of surveillance and control and the resulting self-discipline of employees is the most common used metaphor when discussing the materialization of power relations. Another dimension is the predominantly masculine nature of workplaces reflecting the early twentieth century divide between paid working men and unpaid-work-in-home women (Taylor \& Spicer, 2007). Naturally, the study of the workspace as 
materialization of power relations offers a fertile ground for outcomes impacting human dignity. On the other hand, all intended configurations and arrangements of organizational spaces are subject to the users' interpretations and experiences of them. Van Marrewijk and Yanow (2010, p.5) point out that "a treatment of the intentions of organizational leaders and their architects that assumes that design elements will shape employees' and others' behaviours [sic] without according them agency of their own, and without considering the possibilities of voice or exit, ..., is, today, theoretically and intellectually untenable." While a transition to an open-plan office may mean the loss of status to a manager, it may be a source of empowerment to a clerical employee. Therefore, it is ultimately the individual employee's interpretation of the physical workspace that influences his/her sense of worth, autonomy, comfort, identity and consequently, dignity. Before this meta-conclusion, however, let's look at how researchers have investigated the relationships between the physical environment and the people inhabiting it.

Most research conducted on this theme has devoted attention to specific and objective features of the physical work environment, exploring their effects on the organization or, more often, the employees. We mentioned previously the difficulty of balancing organizational and individual interests when implementing organizational- or job-level practice. Similarly, Elsbach and Pratt (2007) noted in their review that several features of the work space do not univocally associate with positive outcomes; rather they are often a double-edged sword and it is necessary to find the right tradeoff to avoid the paradox of "too much of a good thing" (Pierce \& Aguinis, 2013). Their inventory of the required tradeoffs in planning the physical environment of workspaces is due to the numerous conflicting findings in the literature. Elsbach and Pratt (2007) contend that each element of the physical environment has built-in tensions which pertain to the different functions of the element - aesthetic, instrumental, and symbolic.

Broadly speaking, the classes of characteristics of the physical environment include: (i) the office structure and layout (e.g., enclosed offices vs. open plans, the presence of other barriers, the size), (ii) the office décor and design (e.g., furniture and equipment), and (iii) ergonomic aspects such as lighting, noise, temperature, and air. A summary of the elements and their effects are presented in Table 10.1. These three classes seem to be hierarchically organized in that the structure and layout of offices often shape a number of ergonomic aspects and dictate, to a certain extent, the options available in terms of design and décor. More specifically, the open plans are clearly associated with a higher level of noise and lower privacy than enclosed offices (Barnes, 2007) and constraint individuals in determining their preferred levels of lighting and temperature, which are more often under direct control in traditional offices, with negative effects on employee satisfaction (Carnevale $\&$ Rios, 1995). Similarly, the furniture chosen for an open plan differs considerably from that chosen for an enclosed office and limits the possibility for individuals to personalize their space and décor with photographs, personal mementos and gadgets.

------Insert Table 10.1 about here ------

The layout and structure of offices determines the interactional distance among employees, which decreases as a function of physical closeness. According to Vischer (2007), the biggest factor contributing to worker satisfaction and performance is the floor configuration and layout. In settings where employees are closer to each other, with few to no barriers among them as in the case of open-plan offices, opportunities for communication are higher and it is well-known that a good communication flow is the gatekeeper to cooperation, knowledge sharing and cohesion in groups (Chigot, 2003). Ultimately, collective performance is higher when members of a team share the same mental models, are cognizant of the competencies and knowledge present in the team and trust one another (Mathieu et al., 2000). In sum, it is easy to draw a line connecting the physical structure of 
offices to the employees' job-related performance (McElroy \& Morrow, 2010). Nevertheless, not all social processes activated by physical proximity are positive in nature. It is common observation that interactions with colleagues have suffered at times due to distractions, especially when one is not involved but exposed to others' conversations or to comings and goings of other occupants of the shared office (Sundstrom, 2001). Under these circumstances the visual and acoustic privacy is hindered, which in turn may negatively affect one's emotions and behaviors toward others (e.g., leading people to be less tolerant, more keen on conflict) as well as performance. One of the primary complaints of workers in open-plan offices is indeed the discomfort caused by high levels of noise (Vischer, 2007). While other causes of employee dissatisfaction with open-plan offices include increased frequency of uncontrolled interactions, cognitive overload and stress leading to lower levels of concentration and motivation as well as lack of psychological privacy, noise is described as the factor employees would most like to control (Davis et al., 2011). Given the negative consequences, the love affair with open-plan offices is further unjustified by empirical evidence that enclosure does not reduce the extent of interaction that is essential for performing group tasks, such as information sharing (Knight \& Haslam, 2010).

It seems fair to say that one important moderator of the relationship between physical proximity and social processes, which has the potential to turn it toward the positive or negative end, is task interdependence. While open-plan offices may activate beneficial processes for highly interdependent tasks, the opposite is true when employees are mostly concerned with independent tasks that require cognitive concentration (Smith-Jackson \& Klein, 2009).

In respect of individual states and emotions elicited by the office layout, we observe that they can also assume opposite tones, although in many instances the negative outweigh the positive ones. Open spaces par excellence, but also conventional offices that host several employees, often engender feelings of overcrowding, namely the perception that one's (limited) personal space is being violated. This lack of or intrusion in one's privacy leads in turn to other negative consequences for the person (i.e., higher stress, reduced wellbeing, dissatisfaction with the job) as well as to dysfunctional behaviors for the organization in the form of territoriality (Ayoko et al., 2014; de Croon et al., 2005). Territorial behaviors are actions aimed at increasing one's ownership over the space and are intrinsically neutral. However, when they arise as a reaction to a perceived privacy violation they tend to be defensive, and are, consequently, perceived in negative connotations by the co-workers. Attempts to re-establish distances activate a spiral of contagion that increases the risks of interpersonal conflicts (Brown \& Robinson, 2011). The main theoretical framework that best accounts for the findings cited above is Affective Event Theory (AET; Weiss \& Cropanzano, 1996) as suggested by Ashkanasy et al. (2014). The structure of the office space is not only the scenario where small, day-to-day but powerful events occur; it is, in fact, the catalyst of such events that can be categorized by employees as "invasions", "interferences" and alike, which produce negative emotions. All these aspects of the emotional and psychological wellbeing of every individual can be considered an aspect of dignity at work as suggested by Bolton (2010).

Other events that occur regularly in open-plan offices have to do with being exposed and visible to others. The resulting emotional reactions, that may include frustration and anger (Ashkanasy et al., 2014), are just as likely to be negative due to the power dimension that these events recall. In line with Foucault (1977), these structures foster the feeling of being controlled and distrusted, denying at the same time two basic needs of human beings: autonomy and competence (Deci \& Ryan, 2000). Implications for dignity at work are straightforward, if we converge on defining dignity as the respect and enhancement of the very inner self of every individual.

On the flip side of the coin, other small events such as having a brief chat with a colleague or listening to a funny joke can be categorized as positive by employees and they are also the product of a certain office arrangement. In particular, the possibility to interact with colleagues, 
increased in shared or open offices, counteracts the risks of "unwarranted" privacy (Altman, 1975) fostering a feeling of integration and ultimately satisfying another basic need - relatedness (Deci \& Ryan, 2000). Positive emotions, besides being an end in their own as expression of physical and psychological wellbeing, correlate with a number of desirable outcomes for organizations including job performance, helping and pro-social behaviors, creativity and innovation (Brief \& Weiss, 2002).

The features of the physical work environment that we classified as décor and design have been investigated in the literature primarily in relation to the possibility of personalizing them (Elsbach \& Pratt, 2007). Indeed, this seems to be the most critical aspect - above and beyond the objective characteristics (Carnevale \& Rios, 1995). This approach has its theoretical foundations in the social identity framework (Turner et al., 1994) and sees the ability to personalize the work space or station as the expression of oneself. Identity is socially constructed and multi-level, so that different people have their individual- or group-based identity more salient. All management actions that do not recognize or support either - or both - of these identities will have detrimental consequences (Knight \& Haslam, 2010). Elsbach (2003), for example, showed that people who were moved to a new office and denied the possibility to personalize it, felt threatened in their identity and tried to reaffirm it disregarding the organizational norms. Conversely, Wells (2000) documented that office employees from a variety of organizations were more satisfied with their job and their physical work environment if they were granted the possibility to personalize it, and as a result of their higher satisfaction they reported lower stress.

It is not surprising that often times the physical workspace has been studied in the context of the social environment. The multi-level identities co-exist and the enhancement of the collective identity is also valuable in that it fosters better intergroup relations, effective integration and socialization and reduced conflicts (Ashforth \& Mael, 1989). Furthermore, from a power-based perspective, organizations may tend to level out differences and use the open-plan offices as a reiteration of democratic values and the ultimate abandonment of power and status symbols. However, in doing so they may risk denying employees' personal identity by dissolving it in the group/organizational one. Clearly, this speaks of the relentless dialectic tension between individuation (autonomy) and relatedness that all human beings experience. As Kateb (2011, p.11) observes, "the pathetic fact is that the only enemies of human dignity are human beings". Both autonomy and relatedness needs demand satisfaction, and the equilibrium between them is fluid (Guisinger \& Blatt, 1994). Consequently, the new requirements of the knowledge economy of collaborative work have to be balanced with individual knowledge workers' need for autonomy (Davis et al., 2011). Therefore, most traditional office spaces that emphasize either collaboration (open-plan offices) or autonomy (strictly enclosed offices with sparse or no social spaces) fail to meet the requirements of the office in the $21^{\text {st }}$ century.

Along with the dominant approach dedicated to the study of specific features of the office environment and its effects, another line of investigation is worth mentioning here even though it is less represented. It deals with employee participation in the designing of the office space. As mentioned earlier, dignity at work is a multi-faceted concept that encompasses participation, the possibility for employees to have a say and express their voice. Within this perspective, a study investigated the extent of individual involvement and autonomy over the decisions concerning the office layout, besides some "objective" physical features (Knight \& Haslam, 2010). The results showed that the lack of involvement and autonomy in favor of centralized managerial control over these decisions has a negative effect on psychological comfort and identification, beyond the negative effect of a poor-quality physical space. The way the physical environment affects employee dignity is very much related to the level of psychological comfort associated with the workplace. Vischer (2007) builds a model of three levels of comfort (physical, functional, psychological) and the highest one - psychological - is achieved when there is a high fit between the different elements of 
the physical environment and the task requirements. When people do not feel at ease in a certain environment they also lower their identification with the organization, and this in turn has detrimental consequences on their wellbeing and job satisfaction. Ultimately, a new office design can be a catalyst of organizational change, but if it is badly managed it would lead to resistance and resentment (Davis et al., 2011; Van Marrewijk \& Yanow, 2010).

All in all, current practices of organizing office space are at bewildering odds with the growth of the knowledge economy where professionals with highly specialized skills are becoming more prominent. There is a growing body of studies showing that office workers experience greater discomfort in open plan spaces (Vischer, 2007). Indeed, knowledge work is highly dependent on collaboration of individual employees, but the purported benefit of open-plan spaces in that aspect has largely failed to materialize as there has been no recognition of the diversity of tasks that knowledge workers perform (Davis et al., 2011). Professionals have a greater need for autonomy (Hodson, 2001) and its potential loss causes very honest anxiety as expressed in Baldry and Barnes' (2012, p.243) comment on the introduction of open-plan offices in several universities in the UK and Australia: "If tomorrow's university starts to look like a call centre [sic], this should be taken as a visual index of the extent of the current assault on professionalism." The fact that professionals are almost never consulted on design questions involving their workspaces is an irking issue for them. At the same time, a number of studies shows that involving end-users is a win-win solution both in terms of design and in employees' acceptance and ownership of the changes in their physical workplace (Davis et al., 2011).

\section{Physical space, power and dignity: the road ahead}

Why do we talk about physical space and dignity? Dale and Burrell (2007, p.9) observe that lately "there has been a much more deliberate movement in the conscious design of workplaces to achieve certain values and business goals through the manipulation of space. This is not simply in terms of work ergonomics or to gain greater efficiency, but as an integral element to the impetus of capturing hearts and minds through the use of spatial politics in attempts to manufacture both organisational [sic] culture and appropriate employee identities." Hence, space is an instrument that affects and shapes individuals' emotions, their relationship with co-workers, and gives the possibility to fulfill essential needs and express oneself (Dale \& Burrell, 2007). All these aspects are related with dignity (Bolton, 2010; Hodson, 2001; Sayer, 2014).

Although dignity is associated with many concepts such as respect, pride, recognition, wellbeing, etc., Sayer (2014) prefers to base his discussion of dignity at work on its relationship to autonomy, dependence, seriousness and trust. If we go even deeper, we are bound to reach Kateb's (2011) conclusion that ultimately dignity is about identity. Dignity, like identity, is both personal and social. It is not just about having autonomy, but also about somebody granting and recognizing the autonomy. Human beings are concerned with dignity, because we are deeply aware of our vulnerabilities. In fact, most conflicts arise because of violations of dignity and threats to identity (Hicks, 2011; Sayer, 2014). Dignity, like identity, is socially constructed; it is a negotiated construct between ourselves and society. Similarly, the workspace is also constructed on the negotiation of tradeoffs at different levels (Elsbach \& Pratt, 2007) that emphasize the tensions inherent in virtually all characteristics of the physical environment. These tradeoffs are mapped out to Sayer's (2014) major dignity relationships in Table 10.2. We suggest a corollary that the physical workspace should not be approached statically, but rather dynamically in order to fit with the needs of people in organizations and should be looked at as an ever-changing aspect within a broader ever-changing organic system. Supporting the opinion of Sundstorm (2001), Davis et al. (2011) advocate a systems 
approach to design thinking embedding the workspace environment into the whole organizational system consisting of people, values, culture, processes, and technology. Such an approach would allow for the explicit consideration of necessary tradeoffs as well as needs and requirements of the different system components in design decisions. The authors conclude that "approaches that maximize the involvement of staff and other stakeholders, focus upon the functional and human needs of the office occupants, and are open and transparent, appear more likely to result in successful workspace design than do traditional expert-led push-based approaches to design and change" (Davis et al., 2011, p.219). More importantly, a systems approach cannot ignore the human component assuring at the very minimum protection and possibly promotion of human dignity. Dignity at work is not "achieved" or preserved once and for all; it should be, rather, constantly protected and promoted following the dynamics of evolving systems.

------Insert Table 10.2 about here ------

An inherent component of the relationship between the physical workspace and dignity is the role of the office environment in the politics of power and inequality at work. While the core aspect of dignity is the notion that we are all equally human, the workplace is seethed with inequality - from hierarchies due to job responsibilities to issues such as class, religion, gender, race, etc. Even good intentions such as giving employees freedom to personalize their workstations can backfire as personal artefacts can communicate belongingness to a group of a lower status - e.g. class, ethnicity, nationality - which can result in deniers of dignity. Ironically, the very concept of dignity is entwined in sexism as to what constitutes dignified and undignified behavior of men and women (Sayer, 2014). Consequently, as the inequalities of power are readily translated to the physical environment, they have the potential to serve as barriers to the protection and maintenance of dignity.

While Davis et al. (2011) acknowledge the observation of Elsbach and Pratt (2007) that scholars are unlikely to find a single mechanism explaining the interaction of employees with their physical work environment, they do propose a road of integrating existing theoretical approaches and disparate empirical findings. Their proposition of concentrating on the ability to exert control over one's environment rests on its prominence in social interference theory, cognitive theory and Vischer's (2007) environmental comfort model consisting of three levels of comfort (physical, functional, psychological). The authors support their argument with existing studies relating the freedom to act, move, and control to individuals' wellbeing and creativity at work. Of course, the ability to control one's environment is autonomy. We can link the proposition by Davis et al. (2011) with Pirson and Dierksmeier's (2014) call for reintroducing human dignity to management theory as a potential avenue of improving management theory and its connection to welfare creation. According to economic historians, the unprecedented increase in affluence over the past 200 years cannot be explained by economic factors; instead, it was the granting of unconditional rights and the liberty to define their own lives to individuals that ushered the era of growth and prosperity (Pirson \& Dierksmeier, 2014). Freedom, autonomy, control over one's own choices occur unmistakably in both propositions. Not surprisingly, they are also basic concepts in the notion of dignity together with other ones such as identity, authenticity, equality, character, honor, etc. (Kateb, 2011). Is it possible, then, to suggest that the introduction of human dignity into management theory can serve as that unifying tool of aligning organizational goals and employee wellbeing? To those who doubt a positive answer, let us remind you that the majority of economists were convinced that the abolition of slavery would lead to disastrous economic crashes (Drescher, 2010). Then, dignity can be a solid base for organizational researchers in providing guidelines for the evolving office design. 
Table 10.1 - based on Sundstorm (2001) and Vischer (2007)

\begin{tabular}{|c|c|c|}
\hline $\begin{array}{l}\text { Ambient/Architectural } \\
\text { Factor }\end{array}$ & Aspects & $\begin{array}{l}\text { Employee evaluations and } \\
\text { outcomes }\end{array}$ \\
\hline \multirow[t]{6}{*}{ Office structure and layout } & Open-plan vs. enclosed office & $\begin{array}{l}\text { Employees prefer enclosed } \\
\text { spaces; open-plan associated } \\
\text { with decreased privacy, } \\
\text { friendships and satisfaction }\end{array}$ \\
\hline & Office size and location & Status perceptions \\
\hline & Types of workspace partitions & Privacy perceptions \\
\hline & Amount of storage & $\begin{array}{l}\text { Territoriality and status } \\
\text { perceptions }\end{array}$ \\
\hline & Proximity of workstations & Increased communication \\
\hline & Group meeting spaces & $\begin{array}{l}\text { Group cohesion, team } \\
\text { effectiveness }\end{array}$ \\
\hline \multicolumn{3}{|l|}{ Ergonomics: } \\
\hline \multirow[t]{2}{*}{ Lighting } & Artificial & Deemed adequate \\
\hline & $\begin{array}{l}\text { Daylight - window size and } \\
\text { proximity, view, control of } \\
\text { blinds and glare }\end{array}$ & $\begin{array}{l}\text { Increased comfort and } \\
\text { productivity }\end{array}$ \\
\hline \multirow[t]{2}{*}{ Noise } & Open-plan office noise & $\begin{array}{l}\text { Common source of } \\
\text { dissatisfaction; increased } \\
\text { discomfort and less productivity }\end{array}$ \\
\hline & Music & $\begin{array}{l}\text { Either neutral or positive effect } \\
\text { on performance }\end{array}$ \\
\hline Air quality & $\begin{array}{l}\text { Lack of purity, circulation, } \\
\text { control }\end{array}$ & Discomfort, health issues \\
\hline Temperature & Control of temperature & $\begin{array}{l}\text { Common source of } \\
\text { dissatisfaction }\end{array}$ \\
\hline Workstation & $\begin{array}{l}\text { Seating, equipment, } \\
\text { personalization }\end{array}$ & Performance, satisfaction, health \\
\hline Architectonic details & $\begin{array}{l}\text { Design details, decoration, } \\
\text { artwork }\end{array}$ & $\begin{array}{l}\text { Symbolic significance affecting } \\
\text { emotions }\end{array}$ \\
\hline
\end{tabular}


Table 10.2 - based on Elsbach and Pratt (2007) and Sayer (2014)

\begin{tabular}{|c|c|c|}
\hline $\begin{array}{l}\text { Dimension of Physical } \\
\text { Environment }\end{array}$ & Positive (negative) effects & Dignity relationship \\
\hline \multirow[t]{6}{*}{ High degree of enclosure } & $\begin{array}{l}\text { Increased satisfaction for managers } \\
\text { and professionals; } \\
\text { (Decreased satisfaction for clerical } \\
\text { employees) }\end{array}$ & $\begin{array}{l}\text { autonomy, trust } \\
\text { (dependency) }\end{array}$ \\
\hline & $\begin{array}{l}\text { Improved status perception for } \\
\text { managers }\end{array}$ & trust, seriousness \\
\hline & $\begin{array}{l}\text { Increased job performance and } \\
\text { satisfaction }\end{array}$ & autonomy, trust \\
\hline & Lower fatigue and distraction & autonomy, dependency \\
\hline & Increased privacy & autonomy, trust \\
\hline & $\begin{array}{l}\text { Increased feedback and trust in } \\
\text { management }\end{array}$ & trust, seriousness \\
\hline \multirow[t]{3}{*}{$\begin{array}{l}\text { Adjustable work } \\
\text { arrangements }\end{array}$} & $\begin{array}{l}\text { Control over arrangements more } \\
\text { important than actual arrangements }\end{array}$ & autonomy, trust \\
\hline & $\begin{array}{l}\text { Increased job performance and } \\
\text { satisfaction }\end{array}$ & autonomy, trust \\
\hline & $\begin{array}{l}\text { Increased perceived privacy and } \\
\text { communication }\end{array}$ & autonomy, dependency \\
\hline \multirow[t]{6}{*}{ Personalization } & Increased identity affirmation & $\begin{array}{l}\text { autonomy, trust, } \\
\text { dependency }\end{array}$ \\
\hline & (Lack of seriousness perceptions) & (low seriousness) \\
\hline & Increased positive social climate & $\begin{array}{l}\text { dependency/relatedness, } \\
\text { trust }\end{array}$ \\
\hline & $\begin{array}{l}\text { Higher status associations } \\
\text { (Authority symbols) }\end{array}$ & $\begin{array}{l}\text { trust } \\
\text { (low autonomy) }\end{array}$ \\
\hline & $\begin{array}{l}\text { Increased wellbeing, less stress and } \\
\text { anxiety }\end{array}$ & autonomy, trust \\
\hline & $\begin{array}{l}\text { Increased attachment to place and } \\
\text { organization }\end{array}$ & dependency, trust \\
\hline
\end{tabular}




\section{References}

Altman, I 1975. The environment and social behavior. Monterey, CA: Brooks/Cole.

Ashforth, BE \& Mael, F 198,. 'Social identity theory and the organization', Academy of Management Review, vol. 14, no. 1, pp. 20-39.

Ashkanasy, N, Ayoko, O, \& Jehn, K 2014, 'Understanding the physical environment of work and employee behavior: An affective events perspective', Journal of Organizational Behavior, vol. 35, no. 8, pp. 1169-1184.

Bain, PM \& Taylor, P 2000, 'Entrapped by the "electronic panopticon"? Worker resistance in the call centre', New Technology, Work and Employment, vol. 15, no. 1, pp. 2-18.

Baldry, C \& Barnes, A. 2012, 'The open-plan academy: space, control and the undermining of professional identity', Work, Employment \& Society, vol. 26, pp. 228-245.

Barnes, A 2007, 'The construction of control: The physical environment and the development of resistance and accommodation within call centres', New Technology, Work and Employment, vol. 22, no. 3, pp. 246-259.

Bolton, SC 2010, 'Being Human: dignity of labour as the foundation for the spirit-work connection', Journal of Management, Spirituality \& Religion, vol. 7, no. 2, pp. 157-172.

Brief, AP \& Weiss, HM 2002, 'Organizational behavior: Affect in the workplace', Annual Review of Psychology, vol. 53, no. 1, pp. 279-307.

Brown, G \& Robinson, SL 2011, 'Reactions to territorial infringement', Organization Science, vol. 22, no. 1, pp. 210-224.

Callahan, JL 2013, 'Space, the final frontier? Social movements as organizing spaces for applying HRD', Human Resource Development International, vol. 16, no. 3, pp. 298-312.

Carnevale, DG \& Rios, JM 1995, 'How employees assess the quality of physical work settings', Public Productivity \& Management Review, vol. 18, pp. 221-231.

Carter, C 2008, 'A curiously British story: Foucault goes to business school', International Studies of Management and Organization, vol. 38, no. 1, pp. 13-29.

Dale, K \& Burrell, G 2007, The Spaces of Organisation and the Organisation of Space: power, identity and materiality at work. Palgrave Macmillan.

Davis, MC, Leach, DJ \& Clegg, CW 2011, 'The Physical Environment of the Office: Contemporary and Emerging Issues', in GP Hodgkinson \& JK Ford (eds), International Review of Industrial and Organizational Psychology, Wiley, Chichester, UK, pp. 193-235.

de Croon, EM, Sluiter, JK, Kuijer, PPFM \& Frings-Dresen, MHW 2005, 'The effect of office concepts on worker health and performance: A systematic review of the literature', Ergonomics, vol. 48, no. 2, pp. 119-134.

Deci, EL \& Ryan, RM 2000, 'The "what" and "why" of goal pursuits: Human needs and the selfdetermination of behavior', Psychological Inquiry, vol. 11, pp. 227-268.

Dierksmeier, C 2011, 'Reorienting Management Education: From the Homo Economicus to Human Dignity', in W Amann, M Pirson, C Dierksmeier, E Von Kimakowitz, \& H Spitzeck (eds), Business Schools Under Fire: Humanistic Management Education as the Way Forward, Palgrave Macmillan, pp. 19-40.

Drescher, S 2010, Econocide: British slavery in the era of abolition. University of North Carolina Press.

Edwards, J 2015, 'Google Employees Confess All the Worst Things about Working at Google (GOOG)', Tech Insider, Sep 30, [ http:// finance.yahoo.com/news/google-employees-confessworst-things-125950258.html] - last accessed on Oct 1, 2015.

Elsbach, KD \& Pratt, MG 2007, 'The Physical Environment in Organizations', The Academy of Management Annals, vol. 1, no. 1, pp. 181-224. 
Foucault, M 1977, Discipline and punish: The birth of the prison. Vintage.

Guisinger, S \& Blatt, SJ 1994, 'Individuality and relatedness: Evolution of a fundamental dialectic', American Psychologist, vol. 49, pp. 104-111.

Hackman, JR \& Oldham, GR 1976, 'Motivation through the design of work: Test of a theory', Organizational Behavior and Human Performance, vol. 16, pp. 250-279.

Hicks, D 2011, Dignity: The essential role it plays in resolving conflict. Yale University Press.

Hodson, R 2001, Dignity at work, Cambridge University Press, Cambridge.

Hodson, R \& Roscigno, VJ 2004, 'Organizational Success and Worker Dignity: Complementary or Contradictory?', American Journal of Sociology, vol. 110, no. 3, pp. 672-708.

Kateb, G 2011, Human dignity. Harvard University Press.

Knight, C \& Haslam, SA 2010, 'Your place or mine? Organizational identification and comfort as mediators of relationships between the managerial control of workspace and employees' satisfaction and wellbeing', British Journal of Management, vol. 21, no. 3, pp. 717-735.

Kornberger, M \& Clegg, SR 2004, ,Bringing space back in: Organizing the generative building', Organization Studies, vol. 25, no. 7, pp. 1095-1114.

Mathieu, JE, Heffner, TS, Goodwin, GF, Salas, E \& Cannon-Bowers, JA 2000, 'The influence of shared mental models on team process and performance', Journal of Applied Psychology, vol. 85, no. 2, pp. 273-283.

McElroy, JC \& Morrow, PC 2010, 'Employee reactions to office redesign: A naturally occurring quasi-field experiment in a multi-generational setting', Human Relations, vol. 63, pp. 609-636.

Pierce, JR \& Aguinis, H 2013, 'The Too-Much-of-a-Good-Thing Effect in Management', Journal of Management, vol. 39, no. 2, pp. 313-338.

Pirson, M 2014, 'Dignity-a missing piece in the puzzle of organizational research?', Humanistic Management Network, Research Paper Series, (14-11).

Pirson, M \& Dierksmeier, C 2014, 'Reconnecting management theory and social welfare: A humanistic perspective-dignity as the missing link', Fordham University Schools of Business Research Paper, (2410374), 14-13.

Powell, WW \& Snellman, K 2004, 'The knowledge economy', Annual Review of Sociology, vol. 30, pp. 199-220.

Sayer, A 2007, 'Dignity at work: broadening the agenda.', Organization, vol. 14, no. 4, pp. 565-581.

Smith-Jackson, TL \& Klein, KW 2009, 'Open-plan offices: Task performance and mental workload', Journal of Environmental Psychology, vol. 29, pp. 279-289.

Sundstrom, E 2001, 'Workplace environmental psychology', International Encyclopedia of the Social and Behavioral Sciences, pp. 16593-16598.

Taylor, S \& Spicer, A 2007, 'Time for space: A narrative review of research on organizational spaces', International Journal of Management Reviews, vol. 9, no. 4, pp. 325-346.

Turner, JC, Oakes, PJ, Haslam, SA \& McGarty, CA 1994, 'Self and collective: cognition and social context', Personality and Social Psychology Bulletin, vol. 20, pp. 454-463.

Van Marrewijk, A \& Yanow, D 2010, 'Introduction: The spatial turn in organizational studies', in A Van Marrewijk \& D Yanow (eds), Organizational Spaces: Rematerializing the Workaday World, Edward Elgar Publishing, pp. 1-16.

Vischer, JC 1995, 'Strategic Work-Space Planning', Sloan Management Review, vol. 37, no. 1, pp. 33-42.

Vischer, JC 2007, 'The effects of the physical environment on job performance: towards a theoretical model of workspace stress', Stress and Health, vol. 23, no. 3, pp. 175-184. 